\title{
Errata/Erratum
}

BORTOLOTTI, S. L. V. Avaliação do nível de satisfação de alunos de uma instituição de ensino superior: uma aplicação da Teoria da Resposta ao Item. Gestão \& Produção, São Carlos, v. 19, n. 2, p. 287-302, 2012. http:/ /dx.doi. org/10.1590/S0104-530X2012000200005

Na página 292, a Equação 5 esta incorreta.

\section{Onde lê-se:}

b) $\quad P(U=1 \theta=X) \geq 0,50$

Lê-se:

b)

$$
P(U=1 \theta=X)<0,50
$$

